\title{
Divine Silence in Stefan Heym's The King David Report
}

Vladimir Tumanov

Department of Modern Languages and Literatures, Western University, London, ON N6A 3K7, Canada e-mail: vtumanov@uwo.ca

Neophilologus

An International Journal of Modern and Mediaeval Language and Literature

Volume 93, Number 3, 499-509,

DOI: $10.1007 / \mathrm{s} 11061-008-9109-9$ 


\title{
Divine Silence in Stefan Heym's The King David Report ${ }^{1}$
}

\begin{abstract}
:
This essay deals with Stefan Heym's King David Report as a work of artistically-based biblical scholarship rather than a work of political allegory related to the writer's experience in the East Block during the Cold War. I consider Baruch Halpern's notion of complementary causation (the attribution of causes behind given biblical events to divine and human agency at the same time) in connection to King David's seduction of Bathsheba and the subsequent murder of Bathsheba's husband in 2 Samuel. I try to demonstrate Heym's refusal to attribute complementary causation to the biblical events in order to expose David and Solomon as Machiavellian autocrats rather than instruments of God. Given that (according to Baruch Halpern) the biblical story of David is an apologia of Solomon's illegitimate rule, Stefan Heym's novel undermines the traditional view of Solomon as a Christ type and a great Israelite monarch. Heym's position is contrasted with the deeply ingrained tradition in Judeo-Christian culture of seeing David's life in terms of complementary causation. The conclusion seeks to illustrates Heym's general philosophic stance that makes spirituality and power incompatible.
\end{abstract}

Keywords: Old Testament _ 1 and 2 Samuel _ David and Solomon _ Complementary Causation _ Baruch Halpern _ Divine Intervention _ Bathsheba _ Stefan Heym's King David Report

${ }^{1}$ Published article here:

http://www.springerlink.com/content/k628q65069gq4p0j/?p=cac8ee60d534458fa4c0c93d4c570fe8\&pi=2 
Stefan Heym's retelling of King David's story from the Old Testament (1 and 2 Samuel) in the novel The King David Report has been extensively analyzed with respect to its allegorical implications. Parallels between East Block totalitarianism and the Solomonic court in the Bible are arguably the key purpose of Heym's novel. Its protagonist Ethan ben Hoshaja is given the task of writing "the proper" version of King David's biography for the purpose of propping up King Solomon's claim to power. Conducting his research into the legendary monarch's life, Ethan unearths a great deal of "improper" material which displeases Solomon's repressive court and leads to disastrous consequences for Heym's fictional historian. For his scholarly integrity, the protagonist is sentenced to a symbolic intellectual death: "Now, therefore, let him be silenced to death; let no word of his reach the ear of the people, either by mouth, or by tablet of clay, or by leather; so that his name be forgotten as though he were never born and had never written a line" (Heym, 1997: 247). As K. E. Attar points out, The King David Report thematizes the role of the writer in East Germany: "The accurate presentation of the subject matter subverts the desired propaganda effect, leading to the consequent condemnation of the writer(s) by his/their political employers" (2001: 276). Similarly, Peter Hutchinson explores numerous connections between the events in Heym's retelling of the biblical story and Stalinism: "King Solomon's mines provide a clear parallel to the Siberian slave-labour camps; exemplary confessions and apparently impeccable witnesses parallel the Stalinist 'show trials'; there is corruption and a black market, brutal suppression of all opposition (which includes regular purges), and a secret police" (1986: 133).

Although Stefan Heym was indeed very much preoccupied with the power politics of his own time as he wrote this novel, to quote David Roberts, it would be erroneous to assume "that Heym is using his 'abstract' parable ('Gleichnis') solely as a transparent mask for a satirical attack on the use and abuse of power in the socialist block" (1977: 205). Even without any association with Stalinism or the Soviet realm, the power politics in the biblical material itself are worthy of literary reassessment. The protagonist of 1 and 2 Samuel - 
David, son of Jesse - is a strikingly paradoxical character. One the one hand, King David is perceived traditionally as a hero and perhaps the most important figure in the Old Testament. As Richard Friedman points out, "David stands out because if even half of what the Bible says about him is true, he lived an extraordinary life (1987: 39). David's reign constitutes the high point of the Israelite epic where the Hebrews are united and living in a kingdom that covers more land than before or after David (cf. Friedman,1987: 40). He is the conqueror of Jerusalem where the Israelite temple cult takes root and ends up defining the very meaning of Jewish identity (cf. Friedman, 1987: 92). David's persona lays the foundation for Jewish and subsequently Christian messianism, extending the king's role far beyond his own time (cf. B. Halpern, 2001: 3). In terms of national historic consciousness, whatever precedes and follows David's time is turmoil and fragmentation. Before David the Hebrews are constantly besieged by the Philistines and live as a loose federation of relatively disparate tribes in very precarious circumstances. After David, Solomon's discrimination against all the tribes but Judah causes the northern part of the kingdom to split away from the south, yielding two Jewish states: Judah and Israel (Freidman, 1987: 44-45). Thereafter, only decline follows, reaching its lowest point in Babylonian exile of the $6^{\text {th }}$ century BCE. No wonder David's name "appears more times in the Hebrew Bible than that of any other human person" (Marty J. Steussy, 1990: 3).

And yet, despite his privileged status in Judaism and Christianity, the biblical King David appears as a highly unsavory character who does not shy away from extortion (1 Samuel 25), switching sides in armed conflict (1 Samuel 29) and contract killing (1 Kings 2), just to name a few of the monarch's misdeeds. However, as Peter Hutchinson argues, "although [1 and 2 Samuel] mention [David's] weaknesses and sins against the Lord, they play most of them down in order to give importance to other events" (1986: 132). David's biographer tries to exculpate the protagonist as much as possible in light of the Davidic Covenant, i.e., God's selection of David as a special king whose descendants are to remain on the throne of Judah permanently: 
The Lord declares to you that the Lord will make you a house. When your days are fulfilled and you lie down with your ancestors, I will raise up your offspring after you, who shall come forth from your body, and I will establish his kingdom. He shall build a house for my name, and I will establish the throne of his kingdom for ever. (2 Samuel 7:11-13).

Therefore, an attempt is made to distance David from his crimes by having him bemoan the fate of his victims (Saul's death in 2 Samuel 1:11-12), slay those who do his dirty work (the execution of Saul's Amalekite killer in 2 Samuel 1: 1-16) and appear as a "mock-traitor" (David's service under the Philistine king Achish in 1 Samuel 27: 5-12). And yet, as Baruch Halpern argues with respect to these and other incidents, it is difficult to avoid the feeling that under the apologetic veneer of the biblical narrative we witness a power grab which sets the pattern for countless future autocrats: "Where the author of an ancient text puts himself to the considerable trouble of denying an accusation explicitly, then the historian owes him, at a minimum, the courtesy of taking the accusation seriously. Second Samuel offers a laboratory course of denial" (Halpern, 2001: 80).

However, this denial does not extend to what is arguably the most important and famous of David's dastardly deeds - the Bath-Sheba affair:

It happened, late one afternoon, when David rose from his couch and was walking about on the roof of the king's house, that he saw from the roof a woman bathing; the woman was very beautiful. David sent someone to inquire about the woman. It was reported, 'This is Bathsheba daughter of Eliam, the wife of Uriah the Hittite.' So David sent messengers to fetch her, and she came to him, and he lay with her (2 Samuel 11:1-4).

Following this "royal seduction" David has Uriah the Hittite assassinated and marries Bathsheba. She then bears Solomon, the future heir to the Israelite throne, and the Davidic Covenant (see above) is implemented as the foundation of the Jewish (and subsequently Christian) ideological edifice. What makes the Bathsheba pericope stand out is the divine reaction to David's behavior. The prophet Nathan, speaking for God, spells out in very 
unambiguous terms that this time the king is not gong to "get away with murder": "You have struck down Uriah the Hittite with the sword, and have taken his wife to be your wife, and have killed him with the sword of the Ammonites. Now therefore the sword shall never depart from your house" (2 Samuel 12: 9-10). The events that follow are to be interpreted in terms of the Bathsheba affair.

Baruch Halpern calls this "complementary causation" (47). Analyzing virtually all of the main events from this point on in the biblical text and up to Solomon's ascension to power, Halpern argues that

David's sin [the Bathsheba affair] precipitates divine intervention. But the intervention takes the form of human actors reacting naturally to the circumstances into which they are put, and it is the sum of their actions that accomplishes Yahweh's ends. The implication is that the autonomy of the personalities involved is in some measure compromised (2001: 48).

Thus, David's son Amnon rapes David's daughter Tamar in 2 Samuel 13:1-19. In response to this outrage, David's son Absalom kills Amnon (2 Samuel 13:20-30). This is the first step on the road to Absalom's rebellion against David which eventually culminates in Absalom's death at the hands of David's general Joab (2 Samuel 18:9-15; cf. Halpern, 2001: 361). Eventually all of David's sons, including the eldest Adonijah, are swept out of the way, yielding the terrain to Solomon who takes the throne after David's death: "On its face, Amnon's action [rape of Tamar] seemed to fulfill the punishment Nathan had decreed for Uriah's murder. [...] The logical surmise was that Amnon was Yahweh's implement of vengeance" (Halpern, 2001: 358).

The result is a paradox since good comes out of evil. On the one hand, David's family implodes just as Nathan has predicted. This divinely ordained strife costs David numerous sons and translates into civil war. However, in the end Solomon, allegedly the wisest king in the Old Testament, comes to power - thanks to David's crime. The conclusion is that crime pays, i.e., without the murder of Uriah the theological and national project would be impossible. After all, the son who is to build "God's house" (the Jerusalem temple) in the Davidic 
Covenant (see above) turns out to be Solomon. This is the equivalent of the felix culpa concept relating to Adam and Eve's transgression (Original Sin) in the Garden of Eden pericope from Genesis 2-3. If the first human couple were not to eat the fruit of knowledge in violation of divine interdiction, they would not be cast out of Eden, i.e., from the presence of God. This would make Christ unnecessary since his main function is to reverse original sin by bringing humanity back into the presence of God (salvation). Given the inherent teleology in the Christian epic, original sin is necessary. In the same manner, David's sin is necessary and good: "The child [Solomon] who came to the throne and purged David's establishment was the product of the liaison that caused the struggle for the succession. Solomon heals the tear in the moral fabric of the universe caused by David's and Bathsheba's infidelity" (Halpern, 2001: 404; cf. Hutchinson, 1986: 133)

It is in this connection that Stefan Heym's The King David Report makes a compelling literary argument against the above-mentioned apologia of evil. Since the argument of complementary causation is essential in transforming David's crime into a good deed, Heym retells the Bathsheba affair without the providential element i.e., God is not part of what befalls David's house after the murder of Uriah the Hittite. To begin with, Heym's Nathan - whose counterpart in the biblical text expresses God's outrage at David's treachery actually helps David in the Bath-Sheba affair. In The King David Report, after learning that Bathsheba is pregnant with David's illegitimate child, Nathan reacts as a co-conspirator: "Thus within eight days altogether Uriah could be in Jerusholayim and lie with his wife Bath-sheba and become the father of her child, for who is to say to the day how long a suckling has stayed in the womb of his mother? " (1997: 159). A prophet who assists an adulterer in covering up the adultery is hardly in a position to speak for God so anything that Nathan might say from now is already compromised. Heym's David formulates this very idea in no uncertain terms through his reaction to Nathan's suggestion: "Nathan my friend, if I didn't know you for a prophet, I would say you were a rascal" (1997: 159). 
When the time comes to utter the divine curse in The King David Report, Nathan does exactly what his biblical counterpart does in 2 Samuel 12:1-4. He prefaces the curse with a parable about a rich man who owns many sheep and a poor man who owns only one: "And there came a traveler unto the rich man; but he spared to take of his own flock, nay, he took the poor man's lamb and prepared it for the man that was come to him. [...] You [David] are that man" (Heym, 1997: 165). The parable is meant to sum up David's behavior with respect to Uriah. David is the man with many sheep (wives and concubines) who takes the wife of a man with only one sheep (Bathsheba). The key issue here is that Nathan claims to have been sent by God to tell David the parable, which is of course the case in the Bible. But in Heym's novel, this is explicitly undermined by David's bemused incredulity:

But the King said, I thought there was something surreptitious about your story; now, tell me: did the Lord truly appear to you, or have you been fibbing? [...] either the Lord is truly speaking through you, Nathan, or you are the most insolent man this side of the Jordan, for have you not been part of this from the beginning, and where was your fine righteous voice then? (1997: 165-6)

Instead of epic gravity we have a kind of picaresque effect. The rogue prophet is putting on a front which gives the rogue king a chuckle rather than putting the fear of God into David's soul.

Therefore, when Nathan in The King David Report finally does utter the divine sentence, the reader cannot take it seriously even though Heym's prophet reproduces the biblical text almost verbatim: "Now therefore the sword shall never depart from your house. Behold, I will raise up evil against you out of your own house" (Heym, 1997: 166; cf. above). The absence of any divine content in this prophecy is stressed by the most cynical character in Heym's novel - Benaiah ben Yehoiada who heads King Solomon's secret police. Upon hearing Ethan mention "the story of the heart-warming, tender love of King David and the lady Bath-sheba as related in the book of remembrances of my lord Nathan," Benaiah reacts in the following facetious manner: " 'And you 
believe al that?' Benaiah grinned, displaying his teeth" (Heym, 1997: 167). This toothy grin puts the final nail into the coffin of complementary causation with respect to anything that follows the Bathsheba pericope in The King David Report, i.e., all the events are stripped of providential meaning and must be accounted for only in terms of ruthless human ambition.

Repeated attempts are made by Heym's characters to reintroduce complementary causation into the events - as if they were clinging to the biblical stance. This is how, for example, Nathan describes his state of mind just before he utters his curse to David: "My bowels were filled with fear, but the Lord went on speaking through me unto David" (Heym, 1997: 166). Abiathar the priest even tries to make God an accomplice to David's seduction of Bathsheba: "Did not Lord Yahveh plainly denote his will by his timing of the woman's washing herself and of the sun's setting and of the King's entering upon the roof?" (Heym, 1997: 157-8) But the falseness of such attempts to enlist God into human perfidy is pointed out by David himself during Absalom's rebellion. Referring to his obsequious prophets and priests, David muses: "I know the ways of the men of God: they will try to divine my mind rather than the will of the Lord" (Heym, 1997: 207). In fact, given his position of power, David seems to be the most honest of the cynical characters in the Israelite court. He repeatedly points out that he and his henchmen are on their own, and God's intervention is merely a façade.

However, on the surface, Heym's retelling of what happens after the death of Uriah largely corresponds to the biblical story. For example, in 2 Samuel 12:24 we read the following account of how Solomon is conceived: "Then David consoled his wife Bathsheba, and went to her, and lay with her; and she bore a son, and he named him Solomon. The Lord loved him." And here is how the same event is recounted in Heym's novel: "And David comforted Bath-sheba his wife, and went in unto her, and lay with her, and she bore a son and he called his name Solomon. [...] And the Lord loved Solomon" (Heym, 1997: 175). Similarly, the demise of David's sons - and especially Absolom's rebellion - is retold in The King David Report for the most part as it 
appears in 2 Samuel. The difference between Heym's account and the biblical text is explicable in terms of M. Bakhtin's well-known concept of dialogic discourse:

An author may use the discourse of another for his own goals by giving it new meaning even though the original discourse already possesses and maintains its own meaning. [...] Thus, in the same discourse two meanings or two voices are combined. We find this in parody and stylization. [...] This contingent type of discourse is always bivocal. Only that which used to be non-contingent and serious can become contingent (1979: 219-220; my translation - V.T.). ${ }^{2}$

Heym's reassessment of Nathan's curse outlined above causes the account following the Bathsheba affair to become contingent in Bakhtinian terms. Biblical discourse is hijacked by the author of The King David Report for a purpose entirely different from that of the biblical original. Thus, the abovecited reference to God's love for Solomon ends up filled with dialogic irony in Heym's text because The King David Report does not accept the monologic purpose of 1 and 2 Samuel.

As Baruch Halpern argues, 1 and 2 Samuel were commissioned and written under Solomon's rule as an apologia of David's crimes in order to justify Solomon's illegitimate claim to power (2001: 57). Halpern suggests that Solomon may not even have been David's son (2001: 401-402) and goes on to say that "the apology hardly conceals the fact that Solomon's accession was a coup d'état" (2001: 396). This would explain the teleology of the turmoil in David's house following the Bathsheba affair, with all the events providentially paving the way to Solomon's coronation. Claiming to be David's heir, Solomon was very interested in making David look good by attenuating the trail of blood left by the legendary king. Since Bathsheba was Solomon's mother, linking her with David and stressing Nathan's divine curse (which, as stated earlier, turns

${ }^{2}$ It is noteworthy that Bakhtin was in a situation similar to that of Heym since both wrote under repressive communist regimes. As Gary S. Morson and Caryl Emerson point out, Bakthtin's very treatise on monologic vs. dialogic discourse with respect to Dostoevsky is a form of dialogic discourse in itself because "how else could Bakhtin attack dialectics (Hegelian and Marxist), which he describes as deeply monologic?" (1990: 235). 
out to be a benediction) is perhaps the nucleus of the purpose in 1 and 2 Samuel. It is this manipulation of the truth that Stefan Heym refuses to accept in his attempt to re-imagine the figure of King Solomon.

Solomon is depicted in very negative terms in The King David Report. Here is perhaps the only instance of sincerity on the part of Heym's Nathan as the prophet assesses Solomon: "This one is an imitator, vain, without vision, his dreams mediocre, his verse trite, his crimes growing from fear, not from greatness" (Heym, 1997: 237). Solomon's legendary harem, which holds "seven hundred princesses and three hundred concubines (1 Kings 11:3)," is presented in Heym's novel as a product of cynical cruelty and abuse. Thus, Ethan's own concubine Lilith is simply taken away from him and placed into Solomon's harem:

But Amenhotep [the royal eunuch] placed his arm about my shoulder and steered me gently to my study, where he informed me that in view of the closeness of the arrival of the daughter of Pharaoh [Solomon's bride] it was desired that Lilith my concubine should be delivered unto the royal palace before the sun set another time, so that King Solomon might honour me by accepting her as a handmaid of his wife-to-be (Heym, 1997: 234).

This certainly clashes with the traditional picture of Solomon as a Christ-type, the epitome of wisdom in the Judeo-Christian tradition, the author of numerous psalms and The Song of Songs and especially the man of peace, as the derivation of his name appears to suggest. In fact Heym deliberately places Solomon's positive image in contrast with the king's blood-thirsty ways. Thus, after hearing that his order to execute David's former general Joab has been carried out, "the wisest of Kings, Solomon, seemed much relieved as he returned to his throne " (Heym, 1997: 175; my italics - V.T.). In this manner Heym's highly dialogic text seeks to undermine religious tradition in a fundamental way: heroes are turned into villains.

Heym does not go as far as Halpern, i.e., he does not entertain the notion that Solomon was not David's son. But the author of The King David 
Report is not far away from this position. Heym presents Bathsheba not as a victim of David's lust, but as a wily political manipulator. This is suggested first of all by king David himself who reassesses with suspicion his first glimpse of the bathing beauty from the roof of his palace: "You know, Nathan, I think she planned that. [...] I just feel it" (Heym, 1997: 159). Subsequently Nathan confirms this notion when he tells Ethan that Bathsheba was "a forceful enough personality" to get anything out of King David (Heym, 1997: 165). Similarly, Heym's Solomon admits that Bathsheba's ascent was an act of intellectual effort, i.e., knowledge: "Do you pretend to know better than an old woman in Israel who has become the mother of a king?" (Heym, 1997: 177) Finally, Heym gives the fictional screw one more turn by imagining a conspiracy between Bathsheba and Uriah to create a royal heir. This notion is related by Benaiah ben Yehoiada who appears to know everything as a secret police chief should: "But if you behave wisely, Uriah dear, and do not go home tonight to lie with me, then the child will indubitably be David's" (Heym, 1997: 168).

All this is read by Heym between the lines of the biblical apologia, which is confirmed by Baruch Halpern's research. Halpern considers a rather suspicious pericope in 1 Kings - a book that follows the ideology of 1 and 2 Samuel - where David's eldest son Adonijah appears to usurp the throne while David is still alive:

Now Adonijah son of Haggith exalted himself, saying, 'I will be king'; he prepared for himself chariots and horsemen, and fifty men to run before him. [...] Adonijah sacrificed sheep, oxen, and fatted cattle by the stone Zoheleth, which is beside En-rogel, and he invited all his brothers, the king's sons, and all the royal officials of Judah, but he did not invite the prophet Nathan or Benaiahh or the warriors or his brother Solomon. (1 Kings $1: 5-10$ )

When Nathan hears about this, he goes to Bathsheba and asks her to go see David in order to remind the king of his promise to make Solomon his heir. As Halpern points out, this appears odd because there is no mention of such a 
promise in the preceding biblical text (2001: 392). To quote Marti J. Steussy, "Do Nathan and Bathsheba really recall the king to his promise, or do they simply insinuate one into an old man's memory?" (1990: 81-82) However, when Bathsheba goes to the king and carries out Nathan's instructions, David says to her: "As the Lord lives, who has saved my life from every adversity, as I swore to you by the Lord, the God of Israel, 'Your son Solomon shall succeed me as king, and he shall sit on my throne in my place', so will I do this day." (1 Kings 1:29-30). Thereafter, David orders Solomon anointed for future kingship. Soon after David's death, Adonijah is executed, and Solomon becomes king.

Halpern argues that a careful review of various clues in the biblical text yields a very different picture. Notably, the fact that "the invitees to Adonijah's banquet are 'all the men of Judah, the servants of the king' (1 Kings 1:9) [...] shows that the real royal electorate did stand behind Adonijah's candidacy" (Halpern, 2001: 395). Therefore, in all likelihood, Adonija was in fact David's heir-designate, and Solomon usurped the throne by having Adonijah killed along with all the other sons of David. Heym grasps much of this subtext and expresses it in The King David Report by one small addition to a passage in 1 Kings. After losing his bid for kingship, Adonijah goes to Bathsheba and asks her to secure Solomon's approval for Adonijah's marriage to David's last concubine Abishag. In the biblical text the queen-mother seeks out Solomon and says seemingly innocently: "Let Abishag the Shunammite be given to your brother Adonijah as his wife." (1 Kings 2:21). And here is Heym's version: "There she was again, Bath-sheba the wife of Uriah: butter would not melt in her mouth, but the tip of her tongue carried death. She said, Let Abishag the Shunammite be given to Adonnijah your brother to wife" (Heym, 1997: 184; my italics - V.T.). The biblical Bathsheba is transformed into a Lady Macbeth, and the dialogic impact on the story of Solomon is devastating. The queenmother and her son Solomon are seen here as the perpetrators of a setup against Adonijah. As with all such instances of Bathsheba's scheming in Heym's novel, by implication Solomon's claim to the throne is exposed as 
usurpation. Thus, The King David Report demonstrates that Solomon's apologia of David's life is in fact an apologia of Solomon himself.

Even though Heym deliberately eliminates complementary causation from his version of the Bathsheba affair and the subsequent events, the author of The King David Report does not eliminate God from his novel. Ethan the protagonist is presented as a man of his time who does believe in divine intervention. This is clear from Ethan's prayer to God in the midst of the terrible events and dangers around him: "Have pity, $O$ Lord, on the creatures of your spirit, on those you have fashioned from the clay of this earth. [...] Make haste, O Lord, to deliver me; make haste to help me, O Lord. Let them be ashamed and confounded that seek after my soul: let them be turned backward and put to confusion that desire my hurt" (Heym, 1997: 198). Therefore, Heym preserves the notion of divine intervention in human affairs, i.e., he deals with the biblical word on its own terms instead of adopting a modern historical position. It is simply that he denies divine support to all of David's or Solomon's crimes. This is suggested especially forcefully by the last words of David's general Joab who is about to die on Solomon's orders: "But all this blood I return upon the head of David, who commanded these murders, and upon the head of his seed forever: for it was not shed in the cause of the Lord [...] but for the aggrandizement of the man David" (Heym, 1997: 228-9). Under Heym's critical gaze, the felix culpa concept behind David's crime becomes invalid since no good is allowed to come out of evil.

The importance of providential agency in the destruction of David's family is deeply ingrained in tradition, and this illustrates to what extent the Solomonic apologia has become an accepted part of the Judeo-Christian heritage. For example, in Joseph Heller's novel God Knows - a comicpicaresque retelling of 1 and 2 Samuel - we find a very irreverent narrative (to say the least!) that turns the biblical events on their head. Thus, when David asks Bathsheba why Solomon should become heir to the throne, she replies quite frankly: "Because I suck your cock, that's why. And I'm giving you the greatest fucking you ever had" (Hello, 1984: 332). And yet, despite 
this outrageous treatment of religious tradition, Heller maintains the one serious religious element that turns David's biography into a Solomonic apologia: complementary causation. After David has murdered Uriah, Heller's Nathan pronounces his prophecy in line with what we read in the Bible: "Thus saith the Lord, behold, I will raise up evil against thee out of thine own house [...] because by this deed thou hast given great occasion to the enemies of the Lord to blaspheme." David reacts in the following manner: "I did not dream he was talking about Absalom, and would never have believed it if I'd been told that he was" (Heller, 1984: 323). Here Heller goes beyond the biblical text since the latter makes the divinely ordained link between David's crime and Absalom's rebellion only implicit. Heller's David, however, spells out this connection, establishing complementary causation as the main mechanism of the events leading up to Solomon's coronation. Given Bathsheba's above-cited reason for demanding Solomon's enthronement or such anachronisms, as Bathsheba's claim to have been on the pill while married to Uriah (Heller, 1984: 331), the fact that Heller still keeps complementary causation in God Knows illustrates that we tend to take this notion for granted.

William's Faulkner's Absalom, Absalom! - a major modernist novel loosely based on 1 and 2 Samuel - is an even more striking example of the traditional attitude toward providential agency in David's family relations. Faulkner's story is only indirectly related to the biblical text and religion in general. In fact just the title tips the reader off to look for connections between Absalom, Absalom! and the Bible. The equivalent of the biblical King David is Thomas Sutpen, a rich and ruthless Mississippi landowner who seeks to found a dynasty in the mid-nineteenth century. A self-made man, Sutpen rises from poverty and acquires great wealth. However, he does this through betrayal and callous deeds which in the end bring about the demise of his plan. As in David's case, Sutpen's children destroy each other. The issue of incest plays a major role in this tragedy, evoking the beginning of Absalom's rebellion through Amnon's incestuous relations with Tamar in the Bible. However, even though the biblical God seems to be absent from the events of Faulkner's 
novel, the story of the Sutpen family is still viewed as something analogous to David's sin with Bashsheba. The megalomaniacal Thomas Sutpen sets in motion some sort of providential mechanism like the wrath of God in 2 Samuel. This is how Faulkner approximates the notion of complementary causation in his assessment of Sutpen's downfall: "Fate, destiny, retribution, irony - the stage manager, call him what you will - was already striking the set and dragging on the synthetic and spurious shadows and shapes of the next [scene]" (Faulkner, 1964: 72-3). Faulkner's "stage manager," however metaphoric the author may have intended this image to be, still compromises the autonomy of the characters in some way (see Halpern above) and shifts the tone of the modern novel closer to that of the ancient text.

Heym's desire to sever the link between "the stage manager" and human action with respect to the story of David and Solomon can be seen as part of a general observation on power and philosophy as two antithetic realms of human activity. Discussing Stefan Heym's novel, David Roberts sees The King David Report as a critique of "a venerable tradition which goes back to the Bible, the tradition, that is, of the providential or theocratic interpretation of history [based on] the identity of the needs of power and the will of the Lord, the identity of ends and means" (1977: 205; my italics - V.T.). The notion that spirituality and power are incompatible is probably as old as the practice of conflating ends and means by autocratic rulers. For example, in the New Testament we find Jesus' famous dictum: "Give therefore to the emperor the things that are the emperor's, and to God the things that are God's" (Matt $22: 21)$. Although here Jesus is referring to the need to pay taxes in the Roman Empire, he is also making a philosophic statement about authentic spiritual experience: only the apolitical God is worth thinking about. The king's bombastic rhetoric and the courtier's sycophantic acquiescence are always shadowed by the philosopher's stubborn quest for the truth. The philosopher is sometimes executed and sometimes - banished. Heym's hero, Ethan ben Hoshaja, is banished intellectually by being forbidden to write the truth. However, the idea of the philosophic challenge to all attempts to pass power off 
as spirituality remains. This is why the protagonist of The King David Report cannot bring himself to curse Jerusalem as he leaves Solomon's court, his life in ruins: "I could not do it, for a great splendour of the Lord lay over Jerusholayim in the light of the morning" (Heym, 1997: 252). This contemplation of authentic spirituality - unperturbed by power - closes Heym's novel, providing a perennial alternative to hypocrisy and offering a glimmer of hope for justice.

It is rare that biblical scholars pay much attention to the work of fiction writers who retell stories from the Bible. The history of religion as a modern scholarly discipline normally adheres to a strict methodology based on the objective consideration of evidence, leaving little room for flights of artistic fancy. However, The King David Report constitutes such an astute reading of the biblical text that Baruch Halpern, a major figure in Old Testament research, has the following to say about Heym's achievement: "No novel about the Bible is so accomplished in the historical art as Stefan Heym's brilliant The King David Report (2001: 5). Given the primary place normally attributed to the accomplishment of Thomas Mann in Joseph und seine Brüder, Halpern's assessment is quite monumental. This is why it was proposed earlier that Heym's novel can be viewed quite apart from its allegorical significance and connection to the totalitarian regimes of the twentieth century. The King David Report makes an artistic contribution to biblical scholarship proper by giving the reader a glimpse into the reality of the ancient world. Stefan Heym demonstrates how a careful reading of the Bible can yield fascinating results for anyone who is willing to leave their traditional assumptions behind. 


\section{Works Cited}

Attar, K. E.. "Stefan Heym's King David Report: A Microcosmic Precursor." Neophilologus 85, 2 (Spring 2001): 273-86.

Bakhtin, Mikhail. Problemy poetiki Dostoevskogo. Moscow: Sovetskaia Rossia, 1979.

Bible: New Revised Standard Version.

Faulkner, William. Absalom, Absalom! New York: Random House, Modern Library, 1964.

Friedman, Richard E. Who Wrote the Bible? New York: Summit Books, 1987.

Halpern, Baruch. David's secret demons : Messiah, Murderer, Traitor, King. Grand Rapids, Mich.: W.B. Eerdmans, 2001.

Heller, Joseph. God Knows. New York: Dell, 1984.

Heym, Stefan. The King David Report. Evanston, IL: Northwestern University Press, 1997.

Hutchinson, Peter. "Problems of Socialist Historiography: The Example of Stefan Heym's The King David Report." The Modern Language Review 81, 1 (Winter 1986): 131-138.

Morson, Gary S. and Caryl Emerson. Mikhail Bakhtin: Creation of a Prosaics. Stanford: Stanford University Press, 1990.

Roberts, David. "Stefan Heym: Der Konig David Bericht." Journal of the Australasian Universities Language and Literature Association: A Journal of Literary Criticism, Philology \& Linguistics 48 (1977): 201-11.

Steussy, Marty J. David: Biblical Portraits of Power. Columbia: University of South Carolina Press, 1990.

Taberner, Stuart. "The Writer's Fascination with Power: Stefan Heym's Der König-David-Bericht." Neophilologus 84, 2 (Spring 2000): 271-83. 